\title{
TOPK is highly expressed in circulating tumor cells, enabling metastasis of prostate cancer
}

\author{
Huimin Sun ${ }^{1, *}$, Lei Zhang $2,{ }^{*}$, Changhong $\mathrm{Shi}^{3}$, Peizhen Hu${ }^{4}$, Wei Yan ${ }^{4}$, Zhe Wang ${ }^{4}$, \\ Qiuhong Duan ${ }^{5}$, Fan Lu ${ }^{6}$, Lipeng Qin7, Tao Lu ${ }^{5}$, Juanjuan Xiao ${ }^{5}$, Yingmei Wang ${ }^{4}$, \\ Feng Zhu ${ }^{5}$, Chen Shao ${ }^{1}$ \\ ${ }^{1}$ Department of Urology, Xijing Hospital, The Fourth Military Medical University, Xian, China \\ 2 Department of Epidemiology, Faculty of Preventive Medicine, The Fourth Military Medical University, Xian, China \\ 3 Laboratory Animal Center, The Fourth Military Medical University, Xian, Shaanxi, China \\ ${ }^{4}$ Department of Pathology, Xijing Hospital, The Fourth Military Medical University, Xian, China \\ ${ }^{5}$ Department of Biochemistry and Molecular Biology, School of Basic Medicine, Huazhong University of Science and \\ Technology, Wuhan, China \\ ${ }^{6}$ Department of Biochemistry, Department of Basic Medicine, The Fourth Military Medical University, Xian, China \\ 7 PLA Lhasa General Hospital, Lhasa, China \\ * This authors are Joint first author \\ Correspondence to: Feng Zhu, email: zhufbio@yahoo.com
}

Chen Shao, email: shaochen@fmmu.edu.cn

Keywords: circulating tumor cells, T-LAK cell-originated protein kinase (TOPK), prostate cancer, metastasis

Received: December 13,2014 Accepted: February 26, $2015 \quad$ Published: March 20, 2015

This is an open-access article distributed under the terms of the Creative Commons Attribution License, which permits unrestricted use, distribution, and reproduction in any medium, provided the original author and source are credited.

\section{ABSTRACT}

Circulating tumor cells (CTCs) are important for metastasis in prostate cancer. T-LAK cell-originated protein kinase (TOPK) is highly expressed in cancer cells. Herein, we established a xenograft animal model, isolated and cultured the CTCs, and found CTCs have significantly greater migratory capacity than parental cells. TOPK is more highly expressed in the CTCs than in parental cells and is also highly expressed in the metastatic nodules caused by CTCs in mice. Knocking down TOPK decreased the migration of CTCs both in vitro and in vivo. TOPK was modulated by the PI3K/PTEN and ERK pathways during the metastasis of prostate cancer. High levels of TOPK in the tumors of patients were correlated with advanced stages of prostate cancer, especially for high-risk patients of Gleason score $\geq 8, P S A>20 \mathrm{ng} / \mathrm{ml}$. In summary, TOPK was speculated to be one of a potential marker and therapeutic target in advanced prostate cancer.

\section{INTRODUCTION}

Metastasis is a multi-step process leading to the spread of neoplastic cells to distant sites. The mortality of prostate cancer patients is caused by metastatic deposit in many other tissues and organs, especially in bones and lymph nodes [1]. During metastasis, circulating tumor cells (CTCs) are generated from the primary tumor, and they subsequently invade and colonize distant organs [2]. The presence of CTCs in the blood of patients is a major indicator of metastasis. The CTC population is highly resilient, enabling the cells to colonize a foreign microenvironment $[3,4]$. Therefore, it is important to monitor the number of CTCs in the blood of a patient.

In the early stages of the cancer, CTC numbers can be used to predict the risk of tumor metastasis. During therapy, CTC numbers may be useful in evaluating therapy response or in choosing a suitable therapeutic regimen [59]. The number of CTCs prior to therapy initiation, during, and after therapy, is indicative of the length of progressionfree survival (PFS) and of overall survival (OS) [10-13]. Furthermore, new biological therapeutics that selectively and specifically target CTCs may be developed through the molecular analysis of CTCs $[7,14]$. Clinically, CTCs have been identified as an independent prognostic marker in a number of metastatic cancers [15-16], and a growing 
amount of evidence suggests that CTC monitoring can identify those patients who are responding to or failing therapy early in the course of a treatment [17].

CTCs have been used to detect prostate cancer metastasis and predict the overall survival in patients with metastatic prostate cancer $[18,19]$, thus, further characterizing CTCs may clarify the role of tumor shedding in patients with intermediate- and high-risk prostate cancer [20,21].

T-LAK cell-originated protein kinase (TOPK) belongs to the dual specific serine/threonine kinase MAPKK family, between MEK1/2 and MEK7 [22]. It is highly expressed in some cancers, such as colorectal cancer, breast cancer, and melanoma, and in some fetal tissues, but is lowly or not expressed in normal tissues.

Many studies have demonstrated that TOPK plays an important role in regulating diverse cellular processes, including the proliferation of neural progenitor cells and the development and progression of a variety of human tumors [23-30]. Elevated levels of TOPK may be associated with poor prognosis in a variety of malignant cancers, including hematological cancers, melanoma, colorectal cancers, neuroblastic tumors, and renal cell carcinoma [23-27]. TOPK has also been recognized as a metastasis-promoting kinase in lung cancer metastasis [28].

Extracellular signal-regulated kinases (ERK) have been identified as one of the protein substrates of TOPK/ PBK. Zhu et al. demonstrated that positive feedback between TOPK and ERK2 promotes the tumorigenic properties of colorectal cancer cells [30]. Moreover, Shih et al. showed that TOPK promotes cell migration by modulating the PI3K/PTEN/AKT pathway in lung cancer [28].

CTCs are difficult to detect because of their scarcity and biological heterogeneity. Although TOPK is highly expressed in numerous kinds of tumors, its role in the metastasis of prostate cancer has not been elucidated. In this study, CTCs from prostate cancer were isolated and cultured, and the role of TOPK in the migration of prostate cancer CTCs was studied. Given that TOPK is significantly upregulated in CTCs of prostate cancers and promotes CTC migration and/or invasion, these findings suggest TOPK as a target for therapy and a prognostic marker for metastatic prostate cancer.

\section{RESULTS}

\section{CTCs are more malignant than PC3 cells}

CTCs are a highly heterogeneous population of cancer cells that detach from primary tumors and enter the bloodstream, enabling them to colonize a foreign microenvironment, resulting in tumor metastasis.
In this study, CTCs were isolated and cultured according to the methods that have been reported [31,32], and RBCs were lysed during the isolation. The isolated CTCs were cultured and frozen for future use.

To demonstrate that the isolated cells were CTCs, the cells were stained for the transmembrane protein EpCAM and cytoplasmic keratin 19 (CK19), which are ubiquitously expressed in CTCs [33-35]. The cells were also stained for common leukocyte antigen (CD45) to exclude possible leukocyte contamination [36, 37]. Immunofluorescence showed that the isolated cells were positive for EpCAM and CK19 and negative for CD45 (Figure 1A), indicating that the cells were CTCs.

Next, the proliferation of CTCs and PC3 cells was tested. Comparison of the growth curves of CTCs and PC3 cells demonstrated that CTCs grew faster than PC3 cells (Figure 1B). Furthermore, the proliferation of CTCs or PC3 cells were compared in vivo after subcutaneously injecting $3 \times 10^{6}$ cells into the flanks of mice. The tumors of mice injected with CTCs grew from $0 \mathrm{~mm}^{3}$ to nearly 1000 $\mathrm{mm}^{3}$ within two weeks, whereas tumors grew much slower in mice injected with PC3 cells (Figure 1C). In summary, the above results demonstrate that CTCs proliferate faster both in vitro and in vivo when compared to their parental PC3 cells.

\section{The metastatic capacity of CTCs is stronger than parental PC3 cells}

The presence of CTCs in blood vessels is a major step in metastasis, and CTCs are closely related to metastasis $[1,2]$. Therefore, the migratory and invasive capacities of CTCs and PC3 cells were investigated. In rescue wound healing assays, the scratch created in a CTC culture was nearly completely healed within 24 hours, whereas only half of the scratch created in a PC3 cell culture healed (Figure 2A), suggesting that CTCs migrated faster than PC3 cells. Moreover, in Transwell assays, more CTCs invaded across the membrane than PC 3 cells, demonstrating enhanced invasive capacity (Figure 2B).

Next, the migratory capacities of CTCs and PC3 cells were tested in vivo. Mice were injected intravenously via tail vein with $2 \times 10^{5}$ of either CTCs or PC 3 cells. Two weeks later, the entire lungs of the mice that were injected with CTCs contained metastatic tumors, whereas few tumors were found in the lungs of the mice that were injected with PC3 cells (Figure 2C). These data indicate that CTCs are more metastatic than PC 3 cells both in vitro and in vivo.

\section{TOPK is highly expressed in CTCs}

Together, the data in Figures 1 and 2 demonstrate that CTCs have remarkable proliferative and metastatic capacities. Numerous studies have shown that TOPK 
plays a crucial role in promoting the tumorigenesis [38] and proliferation of cancer cells [39]. Shih et al. reported that TOPK promotes lung cancer metastasis [29], and Wei et al. reported that TOPK is a potential prognostic predictor of stage I lung adenocarcinoma [40]; however, the role of TOPK in metastatic prostate cancer has not been investigated to date.

To test our hypothesis that TOPK might play an important role in the ability of CTCs to mediate prostate cancer metastasis, the expression of TOPK in CTCs was tested.

Immunohistochemical analysis of the lungs of mice intravenously injected with either CTCs or PC3 cells showed that TOPK was more highly expressed in the lungs of the mice that were injected with CTCs than in those injected with PC3 cells (Figure 3A). Moreover, Western blotting showed that TOPK was more highly expressed in CTCs than in PC3 cells (Figure 3B). Because TOPK has been shown to stimulate AKT-dependent cell migration/invasion by relieving PTEN-dependent suppressive effects [28], we also measured the expression of phospho-AKT and phospho-PTEN in the CTCs. These experiments showed that the CTCs had increased Ser473 phosphorylation of AKT and decreased Ser380/
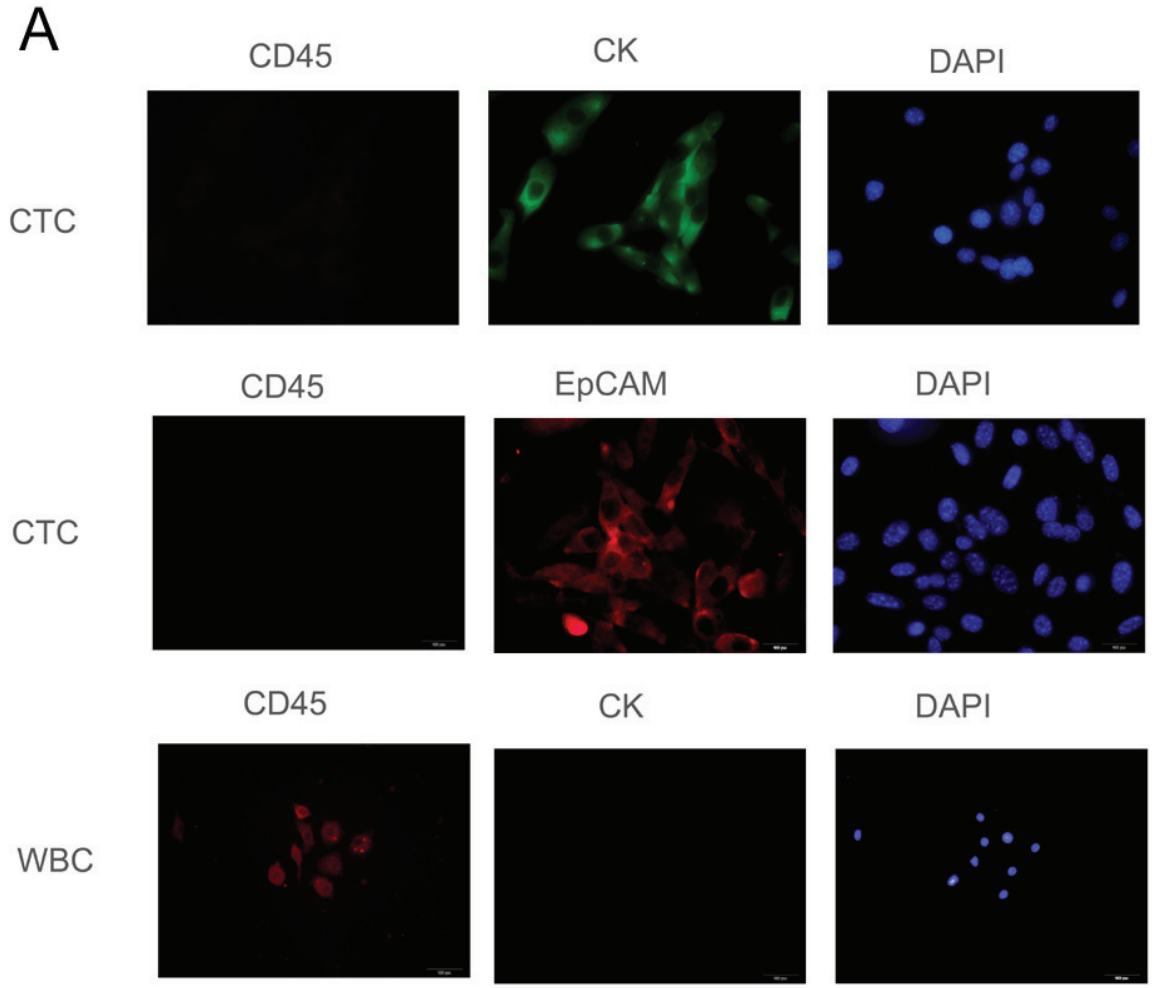

CK

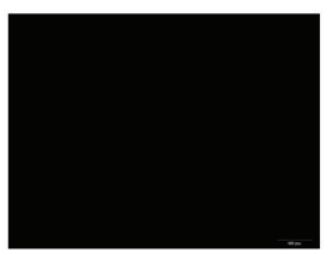

DAPI

B

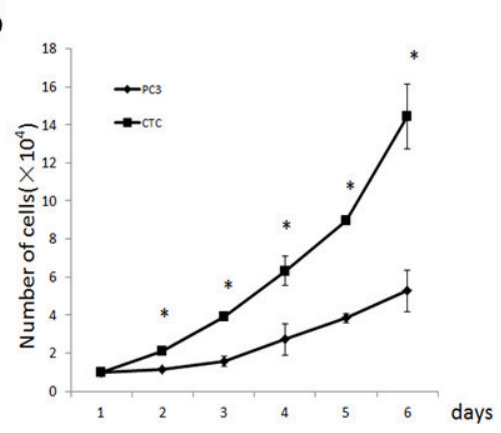

C

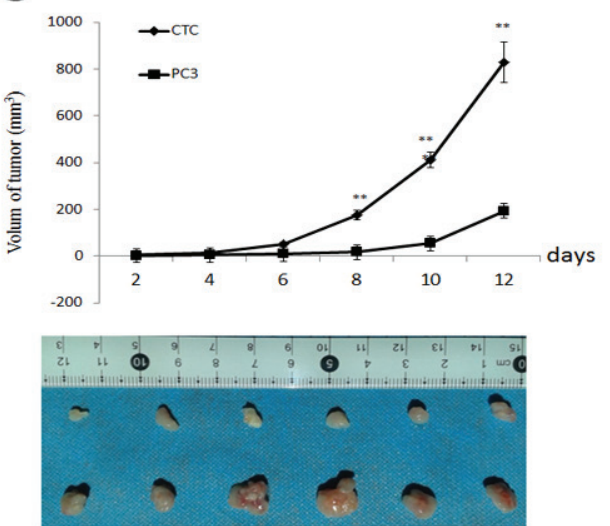

Figure 1: Isolated and cultured CTCs proliferate faster than PC3 cells. A. The isolated cells were identified as CTCs by immunofluorescent staining for EpCaM, CK 19, and CD45. B. The proliferation of CTCs and PC3 cells in vitro. The CTCs grew faster than PC3 cells. C. The proliferation of CTCs and PC3 cells in vivo. The proliferation of CTCs was faster than PC3 cells in vivo. Data represent the mean $\pm \mathrm{SD}$ from three independent experiments, ${ }^{*} p<0.05, * * p 0.01$. 
A
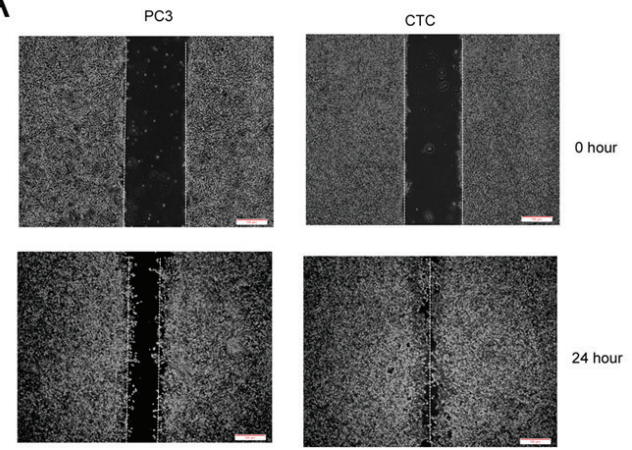

C

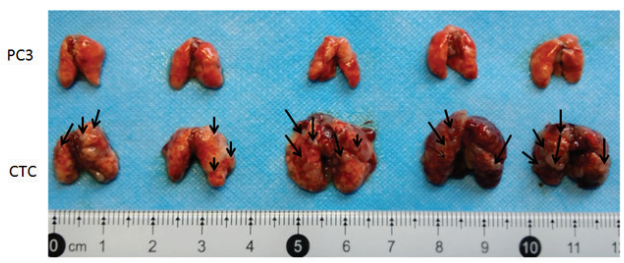

B
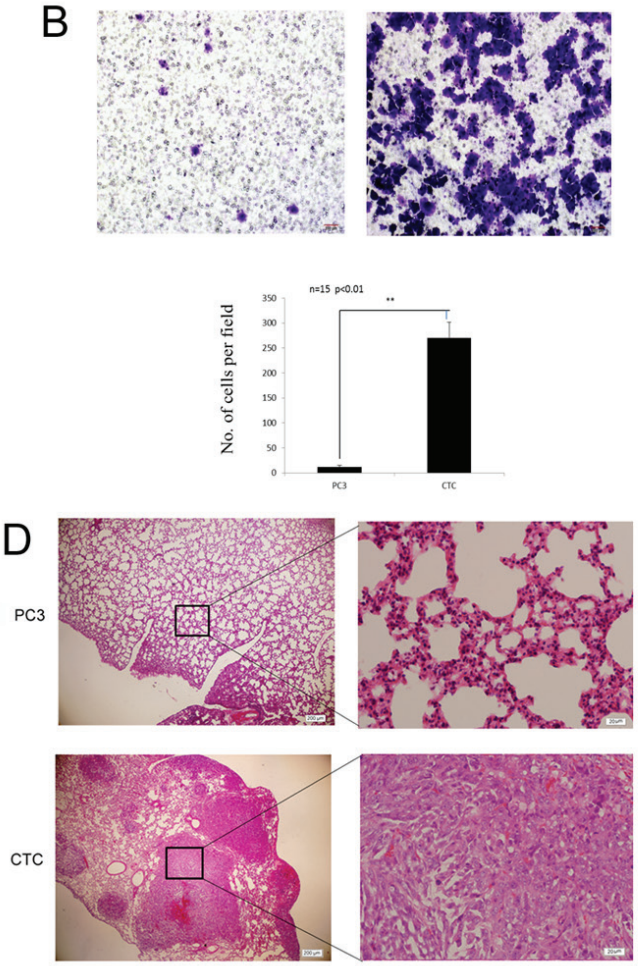

Figure 2: CTCs have greater metastatic capacity than parental PC3 cells. A. Scratch wound assay demonstrating that CTCs migrate faster than PC3 cells. The dotted lines show the area where the scratch wound was created. The scratch wound assay was performed in quadruplicate. B. Transwell invasion assay. CTCs have greater invasive capacity than PC3 cells. Representative images from Transwell invasion assays of PC3 cells (left) and CTCs (right) cells are shown. The results are presented as mean \pm SD of 3 independent experiments $(P<0.01)$. C. Lung metastasis in mice was assessed 14 days following the administration of either CTCs or PC 3 cells via intravenous injection. Grossly visible metastatic nodules were abundant in the CTC group (bottom), but were not obvious in the PC3 group (top). (D) Hematoxylin/eosin-stained lung sections from mice injected with either CTCs or PC3 cells. Poorly differentiated adenocarcinoma cell clusters were found in the lungs of mice in the CTC group. Magnification, $40 \times$ and $400 \times$.
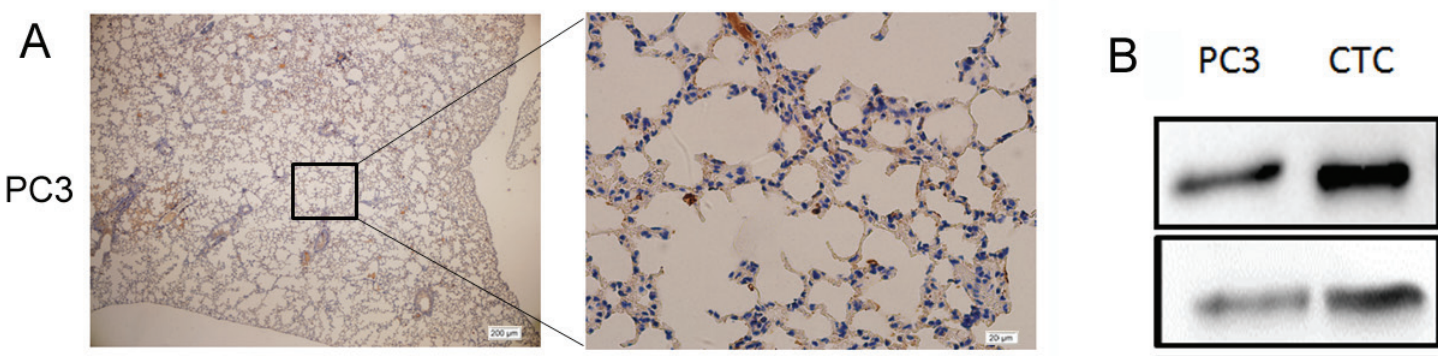

TOPK
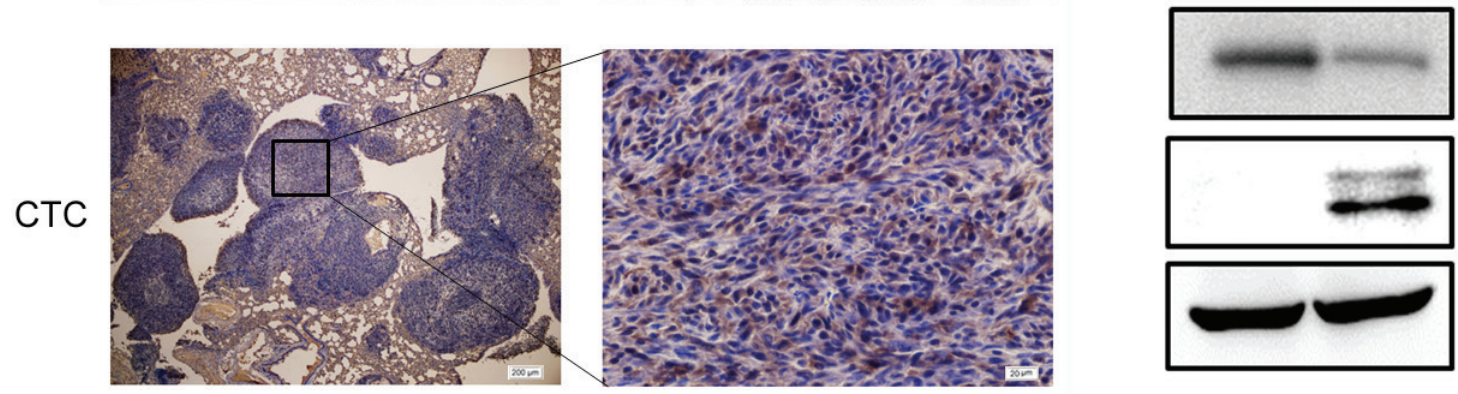

P-AKT

P-PTEN

P-ERK

ACTIN

Figure 3: TOPK is highly expressed in CTCs. A. Immunohistochemical analysis of TOPK expression in lung sections from mice injected with either CTCs or PC3 cells. Nuclear and cytoplasmic expression of TOPK was detected in the pulmonary metastatic CTCs, while no or very weak staining of TOPK was detected in normal pulmonary alveolar epithelial cells from mice in the PC3 group. B. Western blotting was performed to examine the expression of TOPK, phospho-PTEN, phospho-AKT, and phospho-ERK in PC3 cells and CTCs. 
Thr382 phosphorylation of PTEN. Because ERK2 is the substrate of TOPK, and phospho-ERK2 is associated with metastasis [31], we next measured the level of phosphoERK2 in CTCs. Increased ERK2 phosphorylation was observed. All these findings indicate that TOPK signaling is important in CTCs.

\section{Knocking down TOPK prevents CTC metastasis}

In order to further confirm the role of TOPK prostate cancer metastasis, TOPK was knocked down in CTCs through lentiviral transfection. Western blotting demonstrated that the expression of TOPK in CTCshTOPK cells decreased much more remarkably than that in CTCshMOCK cells (Figure 4A).

Next, we examined the migratory and invasive capacity of CTCshMOCK and CTCshTOPK cells in rescue wound healing assays and Transwell assays. The results of rescue wound healing assays demonstrated the scratch created in a CTCshMOCK cell culture healed much faster than the scratch created in a CTCshTOPK cell culture (Figure 4B). Moreover, the results of Transwell assays indicated that more CTCshMOCK cells than CTCshTOPK cells invaded across the membrane within the same time period (Figure 4C). Together, these in vitro assays demonstrate that knocking down TOPK expression in CTCs results in dramatically decreased migratory and invasive capacity.

To test the role of TOPK in the metastatic potential of CTCs in vivo, mice were intravenously injected with $2 \times 10^{5}$ of either CTCshMOCK cells or CTCshTOPK cells. Two weeks later, the pulmonary metastatic tumors were observed. Immunohistochemical staining showed the expression of TOPK was lower in the lungs of the mice that were injected with CTCshTOPK cells than in those injected with CTCshMOCK cells. Importantly, the CTCshMOCK group showed focal hemorrhages, and there were more visible metastatic tumor nodules in the CTCshMOCK group than in the CTCshTOPK group. These findings indicate that knocking down TOPK greatly decreased the ability of CTCs to form tumor metastases in the lung following intravenous injection (Figure 4D and $4 \mathrm{E}$ ). Together, these assays reveal that TOPK plays a very important role in the metastasis of prostate cancer.

The expression of phospho-AKT, phosphoPTEN and phospho-ERK2 in the CTCshMOCK and CTCshTOPK cells were also detected. CTCshTOPK cells showed decreased Ser473 phosphorylation of AKT,
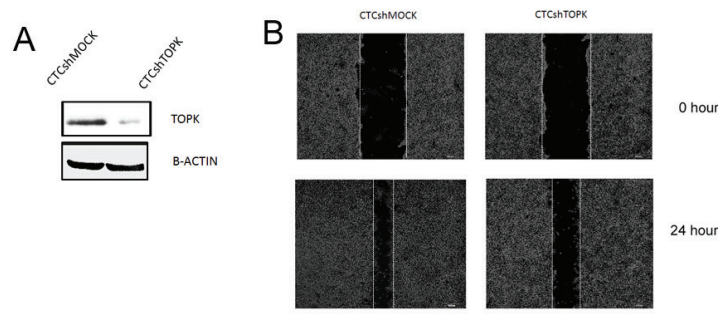

D-1

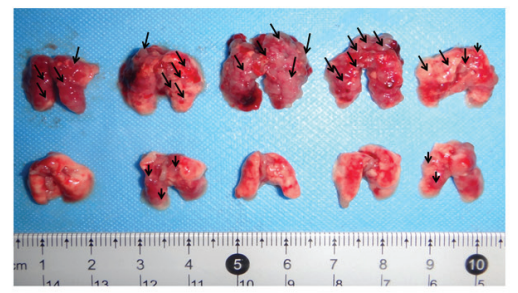

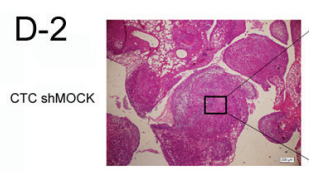
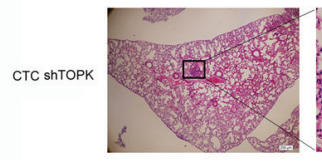
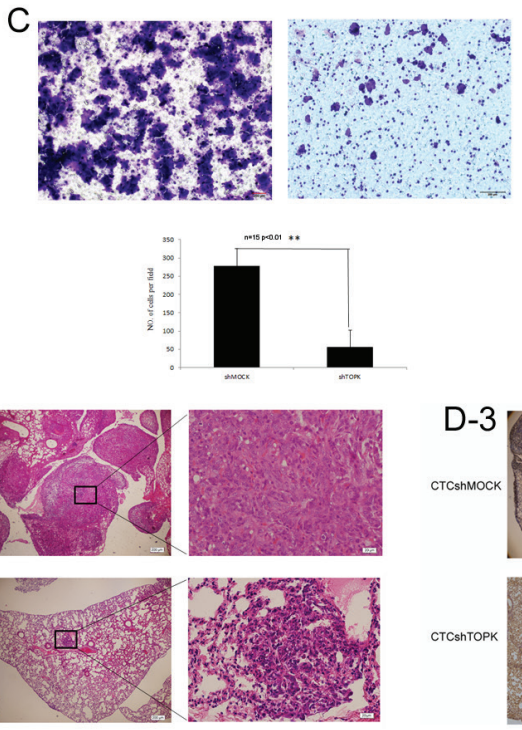

$\mathrm{E}$
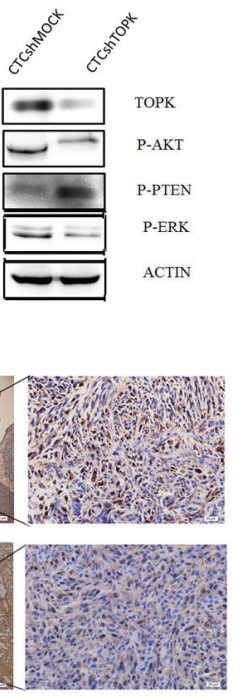

Figure 4: Knocking down TOPK in CTCs decreased their metastatic capacity. A. Expression of TOPK in the CTCshTOPK and CTCshMOCK cell lines. B. Scratch assays performed in CTCshTOPK and CTCshMOCK cells showed that CTCshMOCK cells migrate faster than CTCshTOPK cells. C. Transwell assays of CTCshTOPK (right) and CTCshMOCK (left) cells showed that CTCshMOCK cells have greater invasive capacity than CTCshTOPK cells. D. The metastatic capacity of CTCshTOPK and CTCshMOCK cells in vivo. (D1) Gross examination revealed increased numbers of visible metastatic tumor nodules in the lungs of mice from the CTCshMOCK group compared to the lungs of mice from the CTCshTOPK group. Lungs of mice from the CTCshMOCK group also showed focal hemorrhages (dark red areas of lung surfaces). Arrows indicate tumor metastatic nodules. (D2) Hematoxylin/eosin-stained lung sections from mice injected intravenously with either CTCshMOCK or CTCshTOPK cells. In the CTCshMOCK group, metastatic tumors presented as multifocal nodules, whereas only focal microscopically visible metastases were found in the CTCshTOPK group. Magnification, 40× and $400 \times$. (D3) Immunohistochemical analysis of TOPK expression in pulmonary metastatic nodules. CTCshTOPK metastatic tumor cells showed strong nuclear and cytoplasmic expression of TOPK, whereas normal pulmonary alveolar epithelial cells showed no or very weak expression of TOPK. Magnification, $40 \times$ and $400 \times$ E. The expression of phospho-PTEN, phospho-AKT, and phospho-ERK in CTCshTOPK and CTCshMOCK cells. 


\section{Table 1: Relationship between TOPK expression and clinical diagnostic criteria in 71 prostate cancer patients}

\begin{tabular}{|c|c|c|c|c|}
\hline \multirow[t]{2}{*}{ Variables } & \multicolumn{2}{|c|}{ TOPK expression } & \multirow[t]{2}{*}{ P-value } & \multirow[t]{2}{*}{ Fisher } \\
\hline & $\begin{array}{c}\text { Low }(0,1) \\
(n=49)\end{array}$ & $\begin{array}{l}\text { High }(2,3) \\
(n=22)\end{array}$ & & \\
\hline Level of PSA(ng/ul) & & & 0.02 & 0.017 \\
\hline $\mathrm{PSA} \geqslant 20$ & 15 & 13 & & \\
\hline$P S A<20$ & 34 & 9 & & \\
\hline Gleason grade & & & 0.0016 & 0.0014 \\
\hline$\leqslant 7$ & 31 & 5 & & \\
\hline$\geqslant 8$ & 18 & 17 & & \\
\hline TNM stage & & & 0.035 & 0.0233 \\
\hline Stage $\geqslant T 2 c$ & 18 & 14 & & \\
\hline Stage $<$ T2c & 31 & 8 & & \\
\hline
\end{tabular}

increased Ser380/Thr382 phosphorylation of PTEN, and decreased phosphorylation of ERK2 when compared to CTCshMOCK cells (Figure 4F), further supporting the finding that knocking down TOPK inhibited metastasis in CTCs.

\section{TOPK expression is closely associated with prostate cancer grade}

TOPK expression was examined by immunohistochemistry in 71 human prostate cancer and 30 benign prostatic hyperplasia (BPH) specimens with known clinical follow-up records. High expression of TOPK (scores of 2 and 3) was strongly associated with advanced prostate cancer (Table 1). According to The Guideline for European Association of Urological (EAU), Gleason score $\geq 8, \mathrm{PSA}>20 \mathrm{ng} / \mathrm{ml}$ or stage $>\mathrm{T} 2 \mathrm{c}$ are the borderline range for high risk of prostate cancer metastasis [41]. Overexpression of TOPK in prostate cancer is associated with Gleason score $\geq 8(\mathrm{P}=0.0016), \mathrm{PSA}>20$ $\mathrm{ng} / \mathrm{ml}(\mathrm{P}=0.02)$, and stage $>\mathrm{T} 2 \mathrm{c}(\mathrm{p}=0.035)$.

\section{DISCUSSION}

TOPK plays a role in the development and proliferation of many types of cancers, such as breast, lung, and colon cancers and melanoma, and it is associated with poor prognosis in multiple types of cancer [24-25, 28, 42-44]; however, no studies of the expression of TOPK in prostate cancer have yet been reported. Our study in xenograft animal model demonstrates that TOPK expression is closely associated with the development and proliferation of prostate cancer.

Shih's study demonstrated that TOPK promotes cell migration and invasion in lung cancer [28]. The combination of an integrated microarray with empirical analyses in Shih's study further suggests that TOPK could be a potential prognostic marker for lung cancer. Minoo's study of 399 CRCs showed that TOPK could be a marker of tumor in colon cancer in combination with CDX2, CD44v6, CD44s, nuclear ß-catenin, pERK, APAF-1,

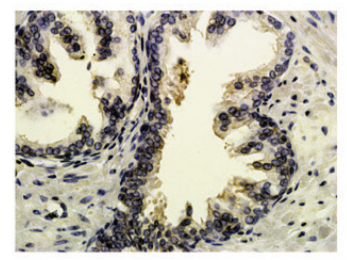

Normal

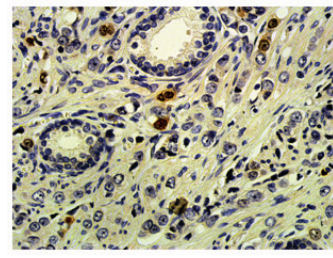

T1

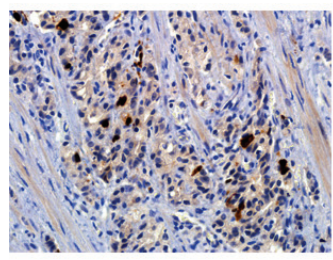

T2

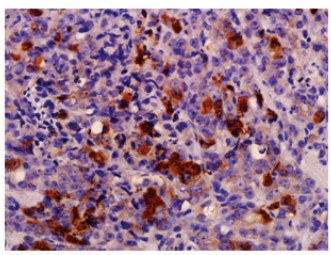

T3

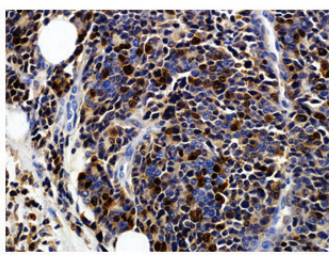

T4

Figure 5: Elevated expression of TOPK is correlated with pathological grade in prostate cancer patients. Normal prostate tissues showed no or very weak expression of TOPK, whereas prostate tumor tissues of high pathological grades showed strong expression of TOPK. 
E-cadherin, p21, and bcl2 [45]. All of these results indicate that TOPK could be a potential tumor marker as well as an important therapeutic target.

The results of our in vitro and in xenograft animal model experiments demonstrate that prostate cancer cells with high TOPK expression have increased migratory and invasive capacity (Figures 2 and 4), and knocking down TOPK decreased the metastatic potential of these cells. Furthermore, we detected differences in the expression of TOPK in BPH prostate tissue and prostate tumor tissues (Figure 5). TOPK expression was lowest in the BPH prostate tissues or tissues adjacent to prostate tumors and was significantly elevated in tumor tissues with high pathological grades (Figure 5). Our analysis of the relationship between TOPK expression and the major clinical diagnostic criteria used in advanced prostate cancer $(\mathrm{PSA} \geq 20 \mathrm{ng} / \mathrm{ml}$, Gleason score $\geq 8$, or Stage $\geq$ $\mathrm{T} 2 \mathrm{c}$ ) in 71 prostate cancer patients also indicated that elevated TOPK expression can be used as an independent prognostic factor in high-risk prostate cancer. However, more cases are required to further validate the role of TOPK before any conclusions can be drawn.

The study by Shih et al. investigated the signaling pathway by which TOPK promotes lung cancer metastasis [28]. Their study indicated that TOPK decreased the protein stability of PTEN by stimulating it to undergo proteasome-dependent degradation. However, it is possible that TOPK could promote cell migration through a PTEN/AKT-independent mechanism. Our study showed that when TOPK was highly expressed, phosphoAKT was also highly expressed, while phospho-PTEN was expressed at low levels (Figure 3B). When TOPK was knocked down, the expression of phospho-AKT was also downregulated, while that of phospho-PTEN was upregulated (Figure 4E). Zhu's study identified a positive feedback loop between TOPK and ERK2 [30]. Accumulating evidence indicates that the ERK pathway can promote the migration and invasion of cancer cells and is closely associated with metastasis [46-49]. Our study demonstrates that when TOPK is highly expressed in CTCs, phospho-ERK is also highly expressed (Figure $3 \mathrm{~B}$ ), and when TOPK is knocked down, the expression of phospho-ERK was also downregulated (Figure 4E). These results are consistent with the previous studies and further indicate that TOPK signaling pathway can promote prostate cancer metastasis by regulating the PTEN/AKT signaling pathway and the ERK pathway. Importantly, all of these pathways have been shown to regulate the growth and metastasis of cancer.

Molecular targeted therapy has been applied to chronic myeloid leukemia, non-small cell lung cancer, colorectal cancer, gastrointestinal stromal tumors, breast cancer, and other tumors [50-58]. Currently, molecular targeted therapies for prostate cancer undergoing clinical trials include therapies against prostate-specific membrane antigen (PSMA) [59] and prostate stem cell antigen
(PSCA) [60], anti-angiogenesis drugs, and anti-tumor cell signaling COX-2 inhibitor drugs [61]. However, at this time, there is no evidence to support the use of molecular targeted therapy in prostate cancer.

Recently, targeted inhibitors against TOPK have been reported, such as HI-032 [62] and OTS964 [63]. In our study in cells and in xenograft animal model, when TOPK was highly expressed, both the cancer cells and the tumors grew faster (Figure 2), the proliferation and development of the cancer cells and tumors were inhibited when TOPK was knocked down (Figure 4). This data suggest that TOPK might be a useful therapeutic target in prostate cancer, inhibiting TOPK might be a useful therapeutic approach in primary and metastatic prostate cancer. Therefore, it is crucial to develop new TOPK inhibitors for prostate cancer targeted therapy.

Numerous reports have demonstrated that the presence of CTCs in the peripheral blood of patients with various forms of metastatic carcinomas is positively associated with poor clinical prognosis [9]. Considering that biopsy is an invasive and painful procedure, the evaluation of CTCs in the blood might represent a potential alternative diagnostic method. Thus, CTCs may become a novel tool for optimizing diagnosis and therapy for patients with early and metastatic cancers [64-66].

Although many methods have been reported for detecting CTCs in the peripheral blood of cancer patients [65-70], there are only a few approaches in use to isolate and culture CTCs $[31,32]$. In this study, we improved and simplified the RBC lysis method for isolating and culturing CTCs. The cells that are isolated with this method can be cultured and passaged continually, making it possible to study the characteristics of CTCs using cultured and passaged CTCs. The approach is quite stable and repeatable and provides easy access to CTCs for researchers.

Based on our findings, high expression of TOPK in CTCs and the experiment in xenograft animal model indicated that TOPK is associated with the metastasis of prostate cancer. We propose that TOPK may serve as a diagnostic marker of high-risk prostate cancer. Moreover, TOPK could be a potential therapeutic target in prostate cancer.

\section{MATERIALS AND METHODS}

\section{Cell culture}

The PC3 prostate cancer cell line was purchased from American Type Culture Collection (ATCC, Rockville, MD, USA). The cells were maintained at $37^{\circ} \mathrm{C}$ in RPMI 1640 medium supplemented with 10\% fetal bovine serum (FBS) in a $5 \% \mathrm{CO}_{2}$ incubator, following the instructions provided by ATCC. 


\section{Xenograft generation}

Non-obese Diabetic/Severe Combined Immunodeficiency (NOD-SCID) mice were purchased from Beijing HFK Bioscience CO., LTD (Beijing, China). The animals were housed in micro-isolator cages with autoclaved bedding and provided autoclaved food and water. A total of $20 \mathrm{NOD} / \mathrm{SCID}$ male mice received injections of $8 \times 10^{5} \mathrm{PC} 3$ prostate cancer cells in 80 $\mu l$ phosphate-buffered saline (PBS; $\mathrm{pH}$ 7.4) into their prostates. The control mice were injected with PBS into the same location. The mice were euthanized for isolation of CTCs eight weeks later.

Athymic Balb/c nude mice were purchased from BEIJING HFK BIOSCIENCE CO., LTD (Beijing, China). PC 3 cells or CTCs $\left(3 \times 10^{6}\right.$ cells suspended in 200 $\mu \mathrm{l}$ PBS) were injected subcutaneously into the right flank of athymic Balb/c nude mice in order to assess the tumor formation capacity of CTCs. The length (l), width (w), and height (h) of the tumor were measured every other day. The volume $(\mathrm{V})$ of the tumor was calculated using the following formula: $\mathrm{V}=0.52(1 \times \mathrm{W} \times \mathrm{h})$. The tumors were dissected and sent for immunohistochemical analysis at the Department of Pathology in Xijing Hospital. All animal experiments were performed following protocols approved by the Laboratory Animal Center of the Fourth Military Medical University.

\section{Orthotopic prostate transplantation}

Mice were anesthetized with $40 \mathrm{mg} / \mathrm{kg}$ pentobarbital by intraperitoneal injection. Under sterile conditions, a $0.6 \sim 0.8 \mathrm{~cm}$ incision was made along the ventral midline abdominal wall. The bladder and seminal vesicles of both sides were gently raised with tweezers, exposing the prostate. The cells were injected at the front and rear sides of the left and right lobes of the prostate, total 4 points, $2 \times 10^{5}$ cells in $20 \mu \mathrm{l}$ PBS $(\mathrm{PH}=7.4)$ were injected into every point. After ensuring nothing was spilled, the abdominal muscles were sutured, the incision was closed, the skin wound was disinfected, and the mice were returned to their cages after waking.

\section{Isolation of circulating tumor cells}

As soon as the mice were euthanized, blood was drawn by means of cardiac puncture following published protocols for obtaining CTCs from mouse blood [31, 32]. The mouse blood (200-900 $\mu$ l per mouse) was pooled into a 2-ml EDTA anticoagulant tube on ice immediately after it was drawn. A 2-ml sample of packed blood cells was lysed with $13 \mathrm{ml}$ of $1 \times \mathrm{RBC}$ lysis buffer $\left(165 \mathrm{mM} \mathrm{NH}_{4} \mathrm{Cl}\right.$, $10 \mathrm{mM} \mathrm{KHCO}_{3}, 0.1 \mathrm{mM}$ EDTA) at room temperature within 10 minutes in a conical tube and then centrifuged for 8 minutes at $1,400 \mathrm{rpm}$ at room temperature in a Central CL2 centrifuge (Thermo IEC). The cells were washed twice by resuspending the pellets in $6 \mathrm{ml}$ of $1 \times$ PBS and centrifuged at $1,400 \mathrm{rpm}$ at room temperature for 3 minutes. The cells left in the tube were cultured in a $5 \% \mathrm{CO}_{2}$ incubator with RPMI 1640 medium supplemented with $10 \%$ fetal bovine serum (FBS). All experiments in the article used the CTCs of passage 5.

\section{Immunofluorescence}

The cells were fixed in 4\% (m:v) paraformaldehyde for $15 \mathrm{~min}$ at $4^{\circ} \mathrm{C}$, washed with $\mathrm{PBS}$, and then permeabilized with $0.3 \%$ Triton $\mathrm{X}-100$ for $10 \mathrm{~min}$ at room temperature (RT). After non-specific binding was blocked with $1 \% \mathrm{BSA}$, the cells were incubated with primary antibody at $4^{\circ} \mathrm{C}$ in a humid chamber overnight. The cells were then incubated with a secondary antibody conjugated to FITC or TRITC for $1 \mathrm{~h}$ at RT. After the cells were washed with PBS, images were taken with an Olympus inverted fluorescent microscope with CCD camera.

\section{Cell growth analysis}

The cells were plated at $1 \times 10^{4}$ cells per well in a 6-well plate and counted in triplicate using a blood counting chamber to generate a growth curve.

\section{Wound healing assay}

We consulted the method in the report of Shi et al [71]. In short, a straight line scratch wound was created in a confluent monolayer of cells using a sterile $1 \mathrm{ml}$ serological pipette. And then washed and continue to culture the cells with RPMI 1640 medium. Images were photographed $100 \times$ magnification using an Olympus Imaging System Microscope at $0 \mathrm{~h}$ and $24 \mathrm{~h}$. The scratch wound assay was performed in quadruplicate.

\section{Migration and invasion (Transwell) assays}

The methods consulted the method in the report of Shi et al [71], briefly, $1 \times 10^{4}$ cells were plated in the matrigel-coated upper chamber of a Corning Costar chamber (Corning, USA). The reservoir of the chamber was filled with complete medium and the cells were cultured continually. 16 hours later, the cells that remained in the top membrane surface were wiped out. The cells that had migrated to the lower surface were stained with crystal violet. Images of migratory cells were photographed $100 \times$ magnification using an Olympus Imaging System Microscope. The cell migration assays were performed in triplicate 


\section{Pulmonary metastasis formation by intravenous injection}

The mice were injected intravenously with $2 \times 10^{5}$ cells. Two weeks later, the mice were euthanized and then dissected. The numbers of metastatic tumors contained in their lungs were counted.

\section{Immunohistochemical staining}

All normal or prostate cancer samples from patients were obtained from the Department of Urology and diagnosed by the Department of Pathology of Xijing Hospital. The expression of TOPK was detected in these samples by immunohistochemistry. The tissue sections were de-paraffinized and rehydrated in PBS. The sections were subjected to antigen retrieval in $10 \mathrm{mM}$ sodium citrate buffer, $\mathrm{pH} 9.0$ for 20 minutes at $100^{\circ} \mathrm{C}$ and washed in PBS. Endogenous peroxidases were quenched in PBS containing $1.5 \% \mathrm{H}_{2} \mathrm{O}_{2}$ for 30 minutes. The samples were rinsed in PBS, blocked in PBS containing 5\% goat serum, and incubated with antibodies $(1: 200)$ to TOPK at RT for 2 hours. The samples were washed in PBS and incubated with a secondary goat anti-mouse antibody (1:500) for 1 hour and incubated with 3, 3'-Diaminobenzidine (DAB) substrate within 3 minutes.

After the mice were euthanized, their lungs and tumors were fixed in $4 \%$ formalin, routinely processed, and embedded in paraffin. Sections of $5-\mu \mathrm{m}$ were placed on glass slides for hematoxylin \& eosin staining and immunohistochemistry (IHC). Microwave heatinduced epitope retrieval in citrate buffer was used for IHC. The tumor and lung sections were stained with the TOPK antibody. Images were obtained at $40 \times$ and $400 \times$ magnification using an Olympus Imaging System Microscope.

\section{Western blotting}

Cells $\left(7 \times 10^{5}\right)$ were cultured in 10 -cm dishes to $70 \%-80 \%$ confluence and harvested in $300 \mu 1$ RIPA buffer. The samples were sonicated 3 times for 15 seconds and centrifuged at 13,000 rpm for 15 minutes. The quantity of protein was determined by the Bradford method. The samples $(30-50 \mu \mathrm{g}$ protein) with $5 \times$ SDS loading buffer were heated at $95^{\circ} \mathrm{C}$ for 10 minutes, cooled on ice, and then were loaded into each lane of a $10 \%$ SDS polyacrylamide gel for electrophoresis (SDS-PAGE) and subsequently transferred onto a PVDF transfer membrane (Millipore, Billerica, MA, USA). Antibody-bound proteins were detected by chemiluminescence (BIO-RAD, USA).

\section{Lentiviral infection}

The lentiviral expression vectors including CTCshTOPK or CTC-shMOCK and packaging vectors including pMD2.0G and psPAX were purchased from Addgene, Inc. (Cambridge, MA, USA). To prepare TOPK viral particles, viral vectors and packaging vectors (pMD2.0G and psPAX) were transfected into HEK293T cells using Lipofectamine 2000 following the manufacturer's suggested protocol. The transfection medium was changed 4 hours after transfection, and then the cells were cultured for 36 hours. The viral particles were harvested by filtration using a $0.22-\mu \mathrm{m}$ syringe filter, then combined with $8 \mathrm{mg} / \mathrm{mL}$ polybrene, and used to infect $60 \%$ confluent CTCs overnight. The cell culture medium was replaced with fresh complete growth medium after 24 hours, and the cells were selected with puromycin $(1.5 \mathrm{mg} / \mathrm{mL})$ after 36 hours. The selected cells were used for experiments.

\section{Antibodies and reagents}

PBK/TOPK mouse monoclonal antibody was purchased from Santa Cruz Biotechnology (Santa Cruz, CA, USA), phospho-p44/42 MAPK (Erk1/2) rabbit monoclonal antibody, phospho-AKT (Ser473) rabbit monoclonal antibody, phospho-PTEN (ser380/ Thr382/382) mouse monoclonal antibody, and EpCAM (VU1D9) mouse monoclonal antibody conjugated to Alexa Fluor 594 were purchased from Cell Signaling Technology, Inc. (Beverly, MA, USA). Cytokeratin 19 rabbit monoclonal antibody was purchased from Abcam, Inc. (Cambridge, MA, USA), CD45 rabbit monoclonal antibody was purchased from Biosen, Inc. (Beijing, China), goat anti-mouse IgG conjugated to FITC and TRITC were purchased from Biosen, Inc. (Beijing, China), goat anti-rabbit IgG conjugated to FITC and TRITC were purchased from Biosen Inc. (Beijing, China), HRP-labeled goat anti-mouse $\operatorname{IgG}(\mathrm{H}+\mathrm{L})$ and goat anti-rabbit $\operatorname{IgG}(\mathrm{H}+\mathrm{L})$ were purchased from SinoBio, Inc. (SuZhou, China), and 4,6-diamino-2-phenyl indole (DAPI) was purchased from Beyotime, Inc. (Beijing, China), Diaminobenzidine (DAB) substrate was purchased from Dako Denmark A/S (Glostrup, Denmark), packaging vectors including pMD2.0G and psPAX were purchased from Addgene Inc. (Cambridge, MA, USA), polybrene were purchased from EMD Millipore (Billerica, MA, USA), puromycin were purchased from Sigma-Aldrich (St Louis, MO, USA).

\section{Statistical analysis}

Significant differences were determined by one-way analysis of variance (ANOVA).

Correlations were determined with Pearson's $\mathrm{x}^{2}$ 
test using SAS9.2 software. All statistical tests were twosided, and $\mathrm{P}<0.05$ was considered significant $(* \mathrm{P}<0.05$, $* * \mathrm{P}<0.01, * * * \mathrm{P}<0.001)$.

\section{ACKNOWLEDGMENTS}

We are grateful to Dr. Leland W. K. Chung, Haiyen E. Zhau, Ruoxiang Wang, Gina Chia-Yi Chu, and Jason Boyang Wu of Cedars-Sinai Medical Center for guiding on the animal experiments and isolating the CTCs, and Dr. Zhaohua Ji of FMMU for guiding on statistical analysis. The study was supported by the major program of international cooperation of the Ministry of Science and Technology of People's Republic of China (No.2011DFA33110), and the grant from the National Natural Science Foundation of China (No. 30100185 \& 30271302).

\section{CONFLICT OF INTEREST}

The authors declare no conflict of interest.

\section{REFERENCES}

1. Gupta GP. Cancer metastasis: building a framework. Cell. 2006; 127: 679-695.

2. Marian L, Katarina K, Vladimir B. Essentials of circulating tumor cells for clinical research and practice. Oncology/ Hematology. 2013; 88: 338-356.

3. de Bono JS, Scher HI, Montgomery RB, Parker C, Miller MC, Tissing H, Doyle GV, Terstappen LW, Pienta KJ, Raghavan D: Circulating tumor cells predict survival benefit from treatment in metastatic castration-resistant prostate cancer. Clin Cancer Res. 2008; 14: 6302-6309.

4. Rossi E, Rugge M, Facchinetti A, Pizzi M, Nardo G, Barbieri V, Manicone M, De Faveri S, Chiara Scaini M, Basso U, Amadori A, Zamarchi R. Retaining the longsurvive capacity of Circulating Tumor Cells (CTCs) followed by xeno-transplantation: not only from metastatic cancer of the breast but also of prostate cancer patients. Oncoscience. 2013;1:49-56.

5. Botteri E, Sandri MT, Bagnardi V, Munzone E, Zorzino L, Rotmensz N, Casadio C, Cassatella MC, Esposito A, Curigliano G, Salvatici M, Verri E, Adamoli L, et al. Modeling the relationship between circulating tumour cells number and prognosis of metastatic breast cancer. Breast Cancer Res Tr. 2010; 122:211-217.

6. Yu M, Stott S, Toner M, Maheswaran S, Haber DA. Circulating tumor cells: approaches to isolation and characterization. J Cell Bio. 2011; 192:373-382.

7. Danila DC, Heller G, Gignac GA, Gonzalez-Espinoza R, Anand A, Tanaka E, Lilja H, Schwartz L, Larson S, Fleisher $\mathrm{M}$, Scher HI. Circulating tumor cell number and prognosis in progressive castration-resistant prostate cancer. Clin Cancer Res. 2007; 13:7053-7058.
8. Okegawa T, Nutahara K, Higashihara E. Prognostic significance of circulating tumor cells in patients with hormone refractory prostate cancer. The J Urol. 2009; 181:1091-1097.

9. Hou JM, Krebs MG, Lancashire L, Sloane R, Backen A, Swain RK, Priest LJ, Greystoke A, Zhou C, Morris K, Ward T, Blackhall FH, Dive C. Clinical significance and molecular characteristics of circulating tumor cells and circulating tumor microemboli in patients with small-cell lung cancer. J Clin Oncol. 2012; 30:525-532.

10. Sarangi S, Mosalpuria K, Higgins MJ, Bardia A. The Evolving Role of Circulating Tumor Cells in the Personalized Management of Breast Cancer: from Enumeration to Molecular Characterization. Curr Breast Cancer Rep. 2014; 6:146-153.

11. Nagrath S, Sequist LV, Maheswaran S, Bell DW, Irimia D, Ulkus L, Smith MR, Kwak EL, Digumarthy S, Muzikansky A, Ryan P, Balis UJ, Tompkins RG, et al. Isolation of rare circulating tumour cells in cancer patients by microchip technology. Nature. 2007; 450:1235-1239.

12. Sakaizawa K, Goto Y, Kiniwa Y, Uchiyama A, Harada K, Shimada S, Saida T, Ferrone S, Takata M, Uhara H, Okuyama R. Mutation analysis of BRAF and KIT in circulating melanoma cells at the single cell level. Brit J Cancer. 2012; 106: 939-946.

13. Cristofanilli, M. Circulating tumor cells, disease progression, and survival in metastatic breast cancer. Seminars Oncol. 2006; 33:S9-14.

14. Kerr BA, Miocinovic R, Smith AK, West XZ, Watts KE, Alzayed AW, Klink JC, Mir MC, Sturey T, Hansel DE, Heston WD, Stephenson AJ, Klein EA, Byzova TV. CD117+ cells in the circulation are predictive of advanced prostate cancer. Oncotarget. 2015; 6:1889-1897.

15. Khoja L, Lorigan P, Zhou C, Lancashire M, Booth J, Cummings J, Califano R, Clack G, Hughes A, Dive C. Biomarker utility of circulating tumor cells in metastatic cutaneous melanoma. J. Invest. J Investigative Dermatology. 2013; 133:1582-1590.

16. Krebs MG, Sloane R, Priest L, Lancashire L, Hou JM, Greystoke A, Ward TH, Ferraldeschi R, Hughes A, Clack G, Ranson M, Dive C, Blackhall FH. Evaluation and prognostic significance of circulating tumor cells in patients with non-small-cell lung cancer. J Clin Oncol. 2011; 29:1556-1563.

17. Tombal B, Van Cangh PJ, Loric S, Gala JL. Value of circulating prostate cells in patients with a rising PSA after radical prostatectomy. Prostate. 2003; 56: 163-170.

18. Moreno JG, Miller MC, Gross S, Allard WJ, Gomella LG, Terstappen LW. Circulating tumor cells predict survival in patients with metastatic prostate cancer. Urology. 2005; 65: 713-718.

19. Scher HI, Jia X, de Bono JS, Fleisher M, Pienta KJ, Raghavan D, Heller G. Circulating tumour cells as prognostic markers in progressive, castration-resistant 
prostate cancer: a reanalysis of IMMC38 trial data. Lancet Oncol. 2009; 10: 233-239.

20. Ide H, Lu Y, Tanaka T, Wakumoto Y, Kitamura K, Muto S, Yamaguchi R, Masumori N, Horie S. Circulating tumor cell count during zoledronic acid treatment in men with metastatic prostate cancer: a pilot study. Prostate Int.2014; 2:147-151.

21. Carvalho FL, Simons BW, Antonarakis ES, Rasheed Z, Douglas N, Villegas D, Matsui W, Berman DM. Tumorigenic potential of circulating prostate tumor cells. Oncotarget. 2013; 4: 413-421.

22. Abe Y, Matsumoto S, Kito K, Ueda N. Cloning and expression of a novel MAPKK-like protein kinase, lymphokine-activated killer T-cell-originated protein kinase, specifically expressed in the testis and activated lymphoid cells. Journal Bio Chem. 2000; 275: 21525 21531.

23. Nandi A, Tidwell M, Karp J, Rapoport AP. Protein expression of PDZ-binding kinase is up-regulated in hematologic malignancies and strongly downregulated during terminal differentiation of HL-60 leukemic cells. Blood Cell Mol Dis. 2004; 32:240-245.

24. Ryu B, Kim DS, Deluca AM, Alani RM. Comprehensive expression profiling of tumor cell lines identifies molecular signatures of melanoma progression. PLoS One. 2007;2:e594.

25. Zlobec I, Molinari F, Kovac M, Bihl MP, Altermatt HJ, Diebold J, Frick H, Germer M, Horcic M, Montani M, Singer G, Yurtsever H, Zettl A, et al. Prognostic and predictive value of TOPK stratified by KRAS and BRAF gene alterations in sporadic, hereditary and metastatic colorectal cancer patients. Brit J Cancer. 2010; 102:151161.

26. Albino D, Scaruffi P, Moretti S, Coco S, Truini M, Di Cristofano C, Cavazzana A, Stigliani S, Bonassi S, Tonini GP. Identification of low intratumoral gene expression heterogeneity in neuroblastic tumors by genomewide expression analysis and game theory. Cancer. 2008;113:1412-1422.

27. Wuttig D, Baier B, Fuessel S, Meinhardt M, Herr A, Hoefling C, Toma M, Grimm MO, Meye A, Rolle A, Wirth MP. Gene signatures of pulmonary metastases of renal cell carcinoma reflect the disease-free interval and the number of metastases per patient. Int J cancer. 2009; 125: 474-482.

28. Shih MC, Chen JY, Wu YC, Jan YH, Yang BM, Lu PJ, Cheng HC, Huang MS, Yang CJ, Hsiao M, Lai JM. TOPK/ PBK promotes cell migration via modulation of the PI3K/ PTEN/AKT pathway and is associated with poor prognosis in lung cancer. Oncogene. 2012; 31: 2389-2400.

29. Simons-Evelyn M, Bailey-Dell K, Toretsky JA, Ross DD, Fenton R, Kalvakolanu D, Rapoport AP. PBK/ TOPK is a novel mitotic kinase which is upregulated in Burkitt'slymphoma and other highly proliferative malignant cells. Blood Cell Mol Dis. 2001; 27: 825-829.
30. Zhu F, Zykova TA, Kang BS, Wang Z, Ebeling MC, Abe Y, Ma WY, Bode AM, Dong Z. Bidirectional signals transduced by TOPK-ERK interaction increase tumorigenesis of HCT116 colorectal cancer cells. Gastroenterology. 2007; 133: 219-231.

31. Ameri K, Luong R, Zhang H, Powell AA, Montgomery KD, Espinosa I, Bouley DM, Harris AL, Jeffrey SS Circulating tumor cells demonstrate an altered response to hypoxia and an aggressive phenotype. Brit J Cancer. 2010; 102: 561 569.

32. Eliane JP, Repollet M, Luker KE, Brown M, Rae JM, Dontu G, Schott AF, Wicha M, Doyle GV, Hayes DF, Luker GD. Monitoring serial changes in circulating human breast cancer cells in murine xenograft models. Cancer Res. 2008; 68: 5529-5532.

33. Stott SL, Lee RJ, Nagrath S, Yu M, Miyamoto DT, Ulkus L, Inserra EJ, Ulman M, Springer S, Nakamura Z, Moore AL, Tsukrov DI, Kempner ME, Dahl DM, Wu CL, Iafrate AJ, Smith MR, Tompkins RG, Sequist LV, Toner M, Haber DA, Maheswaran S. Isolation and Characterization of Circulating Tumor Cells from Patients with Localized and Metastatic Prostate Cancer. Sci Trans Med. 2010; 2: 25 ra23.

34. Deng G, Herrler M, Burgess D, Manna E, Krag D, Burke JF. Enrichment with anti-cytokeratin alone or combined with anti-EpCAM antibodies significantly increases the sensitivity for circulating tumor cell detection in metastatic breast cancer patients. Breast Cancer Res. 2008; 10: R69.

35. Weissenstein U, Schumann A, Reif M, Link S, ToffolSchmidt UD, Heusser P. Detection of circulating tumor cells in blood of metastatic breast cancer patients using a combination of cytokeratin and EpCAM antibodies. BMC Cancer. 2012; 12:206.

36. Kallergi G, Mavroudis D, Georgoulias V, Stournaras C. Phosphorylation of FAK, PI-3 K, and impaired actin organization in CK-positive micrometastatic breast cancer cells. Mol Med Rep. 2007; 13: 79-88.

37. Kallergi G, Markomanolaki H, Giannoukaraki V, Papadaki MA, Strati A, Lianidou ES, Georgoulias V, Mavroudis D, Agelaki S. Hypoxia-inducible factor-1alpha and vascular endothelial growth factor expression in circulating tumor cells of breast cancer patients. Breast Cancer Res. 2009; 11: R84.

38. Hu F, Gartenhaus RB, Eichberg D, Liu Z, Fang HB, Rapoport AP. PBK/TOPK interacts with the DBD domain of tumor suppressor p53 and modulates expression of transcriptional targets including p21. Oncogene. 2010; 29: 5464-5474.

39. Fujibuchi T, Abe Y, Takeuchi T, Ueda N, Shigemoto K, Yamamoto H, Kito K. Expression and phosphorylation of TOPK during spermatogenesis. Dev Growth Differ. 2005; 47: 637-644.

40. Wei DC, Yeh YC, Hung JJ, Chou TY, Wu YC, Lu PJ, Cheng HC, Hsu YL, Kuo YL, Chen KY, Lai JM. Overexpression of T-LAK cell-originated protein kinase predicts poor prognosis in patients with stage I lung 
adenocarcinoma. Cancer Sci. 2012; 103: 731-738.

41. Heidenreich A, Bastian PJ, Bellmunt J, Bolla M, Joniau $\mathrm{S}$, van der Kwast T, Mason M, Matveev V, Wiegel T, Zattoni F, Mottet N. European Association of Urology. EAU guidelines on prostate cancer. Part II: Treatment of advanced, relapsing, and castration-resistant prostate cancer. Euro Urol. 2014; 59:572-583.

42. Park JH, Lin ML, Nishidate T, Nakamura Y, Katagiri T. PDZ-binding kinase/T-LAK celloriginated protein kinase, a putative cancer/testis antigen with an oncogenic activity in breast cancer. Cancer Res. 2006; 66: 9186-9195.

43. Zlobec I, Molinari F, Kovac M, Bihl MP, Altermatt HJ, Diebold J, Frick H, Germer M, Horcic M, Montani M, Singer G, Yurtsever H, Zettl A, et al. Prognostic and predictive value of TOPK stratified by KRAS and BRAF gene alterations in sporadic, hereditary and metastatic colorectal cancer patients. Brit J Cancer. 2010; 102: 151161.

44. O Leary PC, Penny SA, Dolan RT, Kelly CM, Madden SF, Rexhepaj E, Brennan DJ, McCann AH, Pontén F, Uhlén M, Zagozdzon R, Duffy MJ, Kell MR, Jirström K, Gallagher WM. Systematic antibody generation and validation via tissue microarray technology leading to identification of a novel protein prognostic panel in breast cancer. BMC Cancer. 2013; 13: 175.

45. Minoo P, Zlobec I, Peterson M, Terracciano L, Lugli A. Characterization of rectal, proximal and distal colon cancers based on clinicopathological, molecular and protein profiles. Int J Oncol. 2010; 37: 707-718.

46. Hou CH, Lin FL, Hou SM, Liu JF. Cyr61 promotes epithelial-mesenchymal transition and tumor metastasis of osteosarcoma by Raf-1/MEK/ERK/Elk-1/TWIST-1 signaling pathway. Mol Cancer. 2014; 13:236.

47. Song H, Lee AY, Jung H, Choi JH, Roh K, Ha S, Kim KD, Bae KB, Kang MS, Park S, Choi IW, Seo SK, Park S. A8, An Anti-uPA Agonistic Antibody, Promotes Metastasis of Cancer Cells Via ERK Pathway. Monoclon Antib Immunodiagn Immunother. 2014; 33: 312-318.

48. Zhang J, Cao J, Ma S, Dong R, Meng W, Ying M, Weng Q, Chen Z, Ma J, Fang Q, He Q, Yang B. Tumor hypoxia enhances Non-Small Cell Lung Cancer metastasis by selectively promoting macrophage M2 polarization through the activation of ERK signaling. Oncotarget. 2014; 5:96649677.

49. Song KH, Kim SH, Noh KH, Bae HC, Kim JH, Lee HJ, Song J, Kang TH, Kim DW, Oh SJ, Jeon JH, Kim TW. Apoptosis Inhibitor 5 Increases Metastasis via Erk-mediated MMP expression. BMB Rep. 2014; pii: 2880.

50. Vire B, Skarzynski M, Thomas JD, Nelson CG, David A, Aue G, Burke TR Jr, Rader C, Wiestner A. Harnessing the $\mathrm{Fc} \mu$ Receptor for Potent and Selective Cytotoxic Therapy of Chronic Lymphocytic Leukemia. Cancer Res. 2014; 15:7510-7520.

51. Karachaliou N, Rosell R. Systemic treatment in EGFR-
ALK NSCLC patients: second line therapy and beyond. Cancer Biol Med. 2014; 11:173-181.

52. Kirstein MM, Lange A, Prenzler A, Manns MP, Kubicka S, Vogel A. Targeted Therapies in Metastatic Colorectal Cancer: A Systematic Review and Assessment of Currently Available Data. Oncologist. 2014; 19:1156-1168.

53. Casali PG. Successes and limitations of targeted cancer therapy in gastrointestinal stromal tumors. Prog Tumor Res. 2014; 41: 51-61.

54. Vidula N, Rugo HS. Translating the Molecular Message of Triple-Negative Breast Cancer into Targeted Therapy. Clin Cancer Res. 2014; pii: 2532.2014.

55. Lang JE, Wecsler JS, Press MF, Tripathy D. Molecular markers for breast cancer diagnosis, prognosis and targeted therapy. Hellenic J Surg Oncol. 2014; pii: s002449910150.

56. Naderi A, Liu J. Inhibition of androgen receptor and Cdc25A phosphatase as a combination targeted therapy in molecular apocrine breast cancer. Cancer Lett. 2010; 298:74-87.

57. Gee MS, Upadhyay R, Bergquist H, Alencar H, Reynolds F, Maricevich M, Weissleder R, Josephson L, Mahmood U. Human breast cancer tumor models: molecular imaging of drug susceptibility and dosing during HER2/neu-targeted therapy. Radiology. 2008; 248: 925-935.

58. Suter R, Marcum JA. The molecular genetics of breast cancer and targeted therapy. Biologics: Targets Ther. 2007; $1: 241-258$.

59. Zechmann CM, Afshar-Oromieh A, Armor T, Stubbs JB, Mier W, Hadaschik B, Joyal J, Kopka K, Debus J, Babich JW, Haberkorn U. Radiation dosimetry and first therapy results with a (124)I/ (131)I-labeled small molecule (MIP1095) targeting PSMA for prostate cancer therapy. Euro J Nucl Med Mol Imag. 2014; 41:1280-1292.

60. Bargão Santos P, Patel HR. Prostate stem cell antigen - novel biomarker and therapeutic target? Expert Rev Anticancer Ther. 2014;14:5-7.

61. Yerokun T, Winfield LL. LLW-3-6 and celecoxib impacts growth in prostate cancer cells and subcellular localization of COX-2. Anticancer Res. 2014;34: 4755-4759.

62. Kim DJ, Li Y, Reddy K, Lee MH, Kim MO, Cho YY, Lee SY, Kim JE, Bode AM, Dong Z. Novel TOPK inhibitor HI-TOPK-032 effectively suppresses colon cancer growth.. Cancer Res. 2012; 72: 3060-3068.

63. Matsuo Y, Park JH, Miyamoto T, Yamamoto S, Hisada $\mathrm{S}$, Alachkar H, Nakamura Y. TOPK inhibitor induces complete tumor regression in xenograft models of human cancer through inhibition of cytokinesis. Sci Tran Med. 2014; 6:259ra145.

64. Banys M, Müller V, Melcher C, Aktas B, Kasimir-Bauer S, Hagenbeck C, Hartkopf A, Fehm T. Circulating tumor cells in breast cancer. Clin Chim. Acta. 2013; 423:39-45.

65. Nichols AC, Lowes LE, Szeto CC, Basmaji J, Dhaliwal S, Chapeskie C, Todorovic B, Read N, Venkatesan V, Hammond A, Palma DA, Winquist E, Ernst S, et al. 
Detection of circulating tumor cells in advanced head and neck cancer using the CellSearch system. Head Neck. 2012; 34:1440-1444.

66. Patel AS, Allen JE, Dicker DT, Peters KL, Sheehan JM, Glantz MJ, El-Deiry WS. Identification and enumeration of circulating tumor cells in the cerebrospinal fluid of breast cancer patients with central nervous system metastases. Oncotarget. 2011;2:752-760.

67. Allan AL, Keeney M. Circulating tumor cell analysis: technical and statistical considerations for application to the clinic. J Oncol. 2010; 2010: 426218.

68. Miller MC, Doyle GV, Terstappen LW. Significance of circulating tumor cells detected by the CellSearch system in patients with metastatic breast colorectal and prostate cancer. J Oncology. 2010; 2010:617421.

69. Guo M, Li X, Zhang S, Song H, Zhang W, Shang X, Zheng Y, Jiang H, Lv Q, Jiang Y, Hao H. Real-time quantitative RT-PCR detection of circulating tumor cells from breast cancer patients. Int J Oncol. 2015; 46:281-289.

70. Satelli A, Brownlee Z, Mitra A, Meng QH, Li S. Circulating Tumor Cell Enumeration with a Combination of Epithelial Cell Adhesion Molecule- and Cell-Surface VimentinBased Methods for Monitoring Breast Cancer Therapeutic Response. Clin Chem. 2014; pii: 2014.228122

71. Shi H, Wang J, Dong F, Wang X, L i H, Hou Y. The effect of proteoglycans inhibited by RNA interference on metastatic characters of human salivary adenoid cystic carcinoma. BMC Cancer. 2009; 9: 456. 